\title{
Pelatihan Merancang Pembelajaran Online Berbasis E- Learning Bagi Guru dan Calon Guru
}

\author{
Magdalena Wangge \\ Pendidikan Matematika, Universitas Nusa Cendana \\ Email: magdalena.wangge@staf.undana.ac.id
}

\begin{abstract}
One form of application of information and communication technology in the field of education and the requisite due to the current pandemic situation is the application of online learning or E-learning-based online learning. The purpose of this community service activity is to assist teachers and prospective teachers in designing Elearning-based online learning with various media of information and communication technology that they are good at. This service activity is carried out in the form of a webinar and is attended by more than 300 participants. The method used in this research is the method of observation, guidance, and training, discussion, and evaluation. In designing e-learning-based online learning, teachers and prospective teachers need to pay attention to the following: understanding about e-learning, identifying the characteristics of each student, designing and developing interactive material, implementing appropriate teaching strategies in delivering material electronically, organize material well so that it is easy for students to learn, take part in various online training that is held for example webinars to increase knowledge and skills in designing e-learning, involve yourself in every stage from planning, developing, to making decisions, and evaluating learning, both from the teacher's perceptions or from their students
\end{abstract}

Keywords: guru, e-learning, pembelajaran

\section{Sitasi}

Wangge, Magdalena. (2021). Pelatihan merancang pembelajaran online berbasis e-learning bagi guru dan calon guru. Jurnal Nasional Pengabdian Masyarakat, 2(1). 1-10.

\section{Pendahuluan}

Semakin pesatnya perkembangan teknologi informasi dan komunikasi saat ini, tidak dapat terbendung lagi. Akibatnya dari perkembangan teknologi informasi dan komunikasi ini, terjadi pergeseran dalam cara melakukan kegiatan atau aktivitas di berbagai bidang kehidupan masyarakat. Dengan hadirnya berbagai media teknologi informasi dan komunikasi seperti pc, laptop, mobile phone, smartphone, digital tv, emerging platform, audio/video recorder, dan lain sebagainya yang kemudian dihubungkan dengan jaringan internet diantaranya melalui kabel, 4G, DSL, PLC, Satellite, Wireless, Fiber, dan lain-lain. Dengan menggunakan media yang sudah dihubungkan dengan jaringan internet, maka masyarakat dapat dengan mudah mengaplikasikannya dalam berbagai bidang kehidupan termasuk bidang Pendidikan.

Dengan adanya pemanfaatan teknologi informasi dan komunikasi dalam bidang Pendidikan, tentu saja menuntut semua pihak di dalamnya khususnya para guru dan calon guru untuk mampu menguasai penggunaan berbagai teknologi tersebut untuk dapat diterapkan dalam proses pembelajaran. Tujuan dari penguasaan berbagai teknologi informasi dan komunikasi ini antara lain untuk mencapai tujuan pembelajaran dalam Peraturan Menteri Nomor 23 Tahun 2006 tentang Standar Kompetensi Lulusan, baik untuk satuan Pendidikan dasar ataupun menengah (Kemendikbud, 2006). Untuk bisa diaplikasikan berbagai teknologi informasi dan 
komunikasi tersebut kepada peserta didik dalam proses pembelajaran, tentu saja guru harus mempelajari dan menguasainya terlebih dahulu.

Namun kenyataannya di lapangan, masih banyak guru dan calon guru yang belum menguasai penggunaan teknologi informasi dan komunikasi yang berkembang saat ini. Bahkan banyak yang masih bertahan dengan proses pembelajaran atau cara pengajaran yang lama yaitu tanpa memanfaatkan media teknologi informasi dan komunikasi.

Dengan adanya pandemi virus corona atau Covid-19 yang semakin mengganas saat ini, guru dan calon guru tidak punya pilihan lain selain berusaha mempelajari dan menguasai berbagai teknologi informasi dan komunikasi tersebut. Adanya aturan "Belajar dari Rumah" memaksa guru dan calon guru untuk berinovasi dalam merancang suatu proses belajar dengan jarak jauh. Hal ini menjadi suatu keharusan demi menyelamatkan generasi bangsa di tengah situasi pandemi ini.

Salah satu bentuk penerapan teknologi informasi dan komunikasi dalam bidang Pendidikan serta adanya tuntutan akibat situasi pandemi saat ini maka diterapkannya pembelajaran daring atau pembelajaran online berbasis E-learning.

Berdasarkan uraian di atas, maka peneliti berniat membagi pengetahuan dan wawasan yang peneliti miliki kepada para guru dan calon guru terkait bagaimana cara merancang pembelajaran online berbasis E-learning untuk mendukung proses pembelajaran online saat ini. Dengan adanya rencana ini, maka peneliti mengadakan kegiatan webinar sebagai bentuk pengabdian peneliti kepada masyarakat dengan tema "kreatif dan produktif dalam membelajarkan matematika". Dan peneliti menjadi salah satu narasumber dengan materi "Merancang Pembelajaran Online berbasis E-learning".

Tujuan dari kegiatan pengabdian kepada masyarakat ini adalah untuk membantu guru dan calon guru dalam merancang pembelajaran online berbasis E-learning dengan berbagai media teknologi informasi dan komunikasi yang mereka kuasai. Sehingga diharapkan setelah kegiatan pengabdian ini, guru dan calon guru dapat mengatur proses pembelajaran dengan lebih sistematis dan menggunakan media teknologi informasi dan komunikasi yang berkembang saat ini.

\section{Solusi Masalah}

\subsection{Pembelajaran Online}

Menurut Smaldino, Lowther, \& Russell (2007) pembelajaran online merupakan kondisi di mana baik guru maupun peserta didik dapat dengan mudah mengakses dokumen elektronik untuk memperkaya pengetahuan mereka. Dalam pembelajaran online, peserta didik dapat berpartisipasi aktif saat belajar karena pembelajaran online menyediakan perangkat pembelajaran interaktif.

Kegiatan belajar mengajar yang dilakukan oleh para guru, dosen, peserta didik, dan mahasiswa melalui koneksi jaringan internet dan berbagai aplikasi yang mendukung pembelajaran online baik selama proses pembelajaran, pemberian tugas, dan lain-lain (Handarini \& Wulandari, 2020).

Pendapat di atas pun sejalan dengan definisi pembelajaran online menurut Kristina, Sari, \& Nagara (2020), yaitu bahwa pembelajaran online atau daring merupakan kegiatan pembelajaran yang dilaksanakan dengan memanfaatkan berbagai perangkat digital dan internet sehingga pembelajaran menjadi lebih menarik, kreatif, dan mandiri. Pembelajaran 
daring meliputi penyampaian materi dan informasi, pemberian tugas, dan kegiatan interaktif antara guru dan peserta didik selama proses pembelajaran online berlangsung.

Pembelajaran online merupakan pembelajaran yang menggunakan jaringan internet dengan aksesibilitas, konektivitas, fleksibilitas, dan kemampuan untuk memunculkan berbagai jenis interaksi pembelajaran (Firman \& Rahman, 2020).

Dari uraian di atas, maka peneliti menyimpulkan bahwa pembelajaran online merupakan kegiatan belajar yang interaktif antara guru dan peserta didik dengan menggunakan media teknologi dan informasi yang tepat dan sesuai serta sudah terkoneksi dengan jaringan internet.

\subsection{E-learning}

E-learning merupakan teknologi informasi dan komunikasi untuk mengaktifkan peserta didik untuk belajar kapan pun dan di mana pun (Dahiya, 2012). Hal ini sejalan dengan pendapat dari Munir yang menyatakan bahwa e-learning merupakan sebuah bentuk teknologi informasi yang diterapkan di bidang Pendidikan dalam bentuk dunia maya. Istilah e-learning itu sendiri lebih tepat ditujukan sebagai sebuah upaya untuk membuat sebuah transformasi proses pembelajaran yang ada di sekolah ataupun perguruan tinggi ke dalam bentuk digital yang dijembatani teknologi internet (Munir, 2009).

E-learning merupakan bentuk pedagogik baru dalam pembelajaran abad ke-21 saat ini, dimana guru berperan sebagai perancang, fasilitator dalam proses interaksi, dan ahli materi pembelajaran (Seok, 2008).

Ada pula pendapat lain yang menyatakan bahwa e-learning merupakan sembarang pengajaran dan pembelajaran yang menggunakan rangkaian elektronik seperti LAN, WAN, atau internet dalam menyampaikan isi pembelajaran, interaksi, ataupun bimbingan (Koran, 2002). Pendapat ini hampir serupa dengan yang disampaikan oleh Sutanta (2009), yaitu suatu jenis sistem pembelajaran yang memungkinkan tercapainya bahan ajar ke peserta didik dengan menggunakan media internet, intranet atau media jaringan computer lainnya.

Dari uraian di atas, maka peneliti menyimpulkan bahwa e-learning adalah cara pengajaran dan pembelajaran yang menggunakan media elektronik (internet, intranet, satellite, audio/video record, computer/pc, smartphone) untuk menyampaikan bahan ajar maupun interaksi antara guru dan peserta didik.

\subsection{Pembelajaran Online Berbasis E-learning}

Dari uraian definisi pembelajaran online dan e-learning, maka menurut peneliti pembelajaran online berbasis e-learning merupakan kegiatan belajar yang interaktif antara guru dan peserta didik dengan menggunakan media elektronik (internet, intranet, satellite, audio/video record, computer/pc, smartphone).

Pembelajaran online berbasis e-learning pada pelaksanaannya membutuhkan perangkat pendukung seperti smartphone, pc, dan laptop untuk dapat mengakses informasi di mana saja dan kapan saja (Gikas \& Grant, 2013). Selain itu, teknologi yang digunakan pun memiliki kontribusi besar dalam bidang Pendidikan khususnya dalam mencapai tujuan pembelajaran jarak jauh (Korucu \& Alkan, 2011).

Adapun berbagai media yang dapat digunakan untuk mendukung pembelajaran daring berbasis e-learning diantaranya kelas virtul via Google Classroom, Edmodo, dan Schoology (Enriquez, 2014; Sicat, 2015; Iftakhar, 2016), dan aplikasi pesan instan misalnya Whatsapp 
(So, 2016) pembelajaran online berbasis e-learning bahkan dapat dilaksanakan melalui media sosial seperti Facebook dan Instagram (Kumar \& Nanda, 2018).

Pendapat di atas sejalan dengan yang disampaikan oleh Oknisih, Yull, \& Suyoto yaitu bahwa ada beberapa aplikasi yang membantu kegiatan belajar mengajar, misalnya Whatsapp, Zoom, Web Blog, Edmodo, dan lain-lain. Selain itu ada aspek-aspek yang perlu diperhatikan seperti aspek produk, aspek proses, sikap, dan aplikasi. Tujuan dari penggunaan aplikasi online ini adalah untuk melatih kemandirian dan keaktifan peserta didik (Oknisih, Yull, \& Suyoto; 2019).

Beberapa karakteristik dari pembelajaran online berbasis e-learning menurut Clark \& Mayer (dalam Mahnun, 2018), yaitu:

1) harus memiliki dua unsur penting, informasi dan metode pengajaran yang memudahkan dalam memahami konten pelajaran;

2) dilaksanakan melalui komputer menggunakan tulisan, suara, atau gambar seperti ilustrasi, photo, animasi, dan video;

3) untuk membantu guru mengajar seorang peserta didik secara objektif.

Karakteristik lain menurut Henderson (2003) yaitu memungkinkan peserta didik belajar tanpa harus ke ruang kelas dan jadwal kegiatan belajar mengajar pun berdasarkan kesepakatan bersama antara guru dan peserta didik.

\section{Metode Pelaksanaan}

Metode yang digunakan dalam penelitian ini adalah metode observasi, bimbingan dan pelatihan, diskusi serta evaluasi. Dalam metode observasi, peneliti dengan kedua rekan dosen yang menjadi narasumber dalam kegiatan webinar melakukan diskusi terkait topik yang sedang hangat saat ini berkaitan dengan Pendidikan dalam situasi pandemi ini. Dan tercetuslah ide untuk melaksanakan kegiatan webinar dengan tema "kreatif dan produktif dalam membelajarkan matematika", dimana salah satu materi yang disajikan oleh peneliti yaitu "Merancang Pembelajaran Online Berbasis E-learning". Meskipun dari tema tampak hanya mengkhususkan guru dan calon guru matematika, namun tidak menutup kemungkinan guru dan calon guru dari bidang studi lain ikut bergabung.

Dalam metode bimbingan dan pelatihan, peneliti menyajikan materi terkait bagaimana merancang pembelajaran online berbasis e-learning dengan menggunakan berbagai media teknologi informasi dan komunikasi yang sudah dikuasai dan yang ingin dikuasai oleh guru dan calon guru. Jadi merancang pembelajaran online berbasis e-learning ini bukan hanya dikhususkan pada satu jenis media saja, tergantung dari pilihan para peserta webinar. Jadi bimbingan dan pelatihan dimulai dengan menanamkan konsep terkait bagaimana merancang pembelajaran online berbasis e-learning, kemudian dilanjutkan dengan contoh penerapan media teknologi informasi dan komunikasi untuk merancang e-learning. Kegiatan pengabdian ini dilaksanakan dalam bentuk webinar yang diikuti lebih dari 300 peserta yang terdiri dari para guru dan calon guru (mahasiswa Pendidikan keguruan) dari berbagai sekolah dan universitas di Nusa Tenggara Timur bahkan dari luar Nusa Tenggara Timur.

Dalam metode diskusi, tentu saja disediakan sesi diskusi dan tanya jawab selama proses webinar berlangsung. Selanjutnya metode evaluasi, merupakan bentuk penilaian akhir setelah seluruh proses kegiatan pengabdian dalam bentuk webinar ini berakhir.

\section{Hasil Pelaksanaan dan Diskusi}




\subsection{Observasi}

Kegiatan observasi ini dilakukan 2 minggu sebelum kegiatan webinar dijadwalkan, namun tidak dapat dilakukan dengan langsung turun ke lapangan untuk mengidentifikasi beberapa permasalahan yang ditemukan, dikarenakan situasi pandemi yang belum berakhir. Peneliti bersama dua rekan dosen melakukan diskusi dan sharing pengalaman terkait topik-topik yang sedang hangat di kalangan para guru ataupun mahasiswa calon guru di tengah pandemi Covid-19 ini. Peneliti bersama kedua rekan memikirkan hal-hal apa saja yang dapat membantu para guru serta calon guru ini untuk tetap menghasilkan sesuatu yang sesuai dengan bidang kemampuannya dan pekerjaannya meskipun dibatasi masa pandemi.

Dari hasil diskusi dan observasi, maka peneliti dan kedua rekan mencetuskan ide untuk mengadakan kegiatan webinar dengan tema "kreatif dan produktif dalam membelajarkan matematika". Namun peneliti dan kedua rekan dosen sebagai narasumber, menyajikan 3 topik materi yang berbeda. Hal ini dimaksudkan agar para peserta, dalam hal ini para guru dan calon guru mendapatkan banyak hal baru yang diharapkan dapat bermanfaat bagi mereka. Dan materi pertama yang disajikan adalah "Merancang pembelajaran online berbasis $e$ learning" dengan peneliti sebagai narasumbernya.

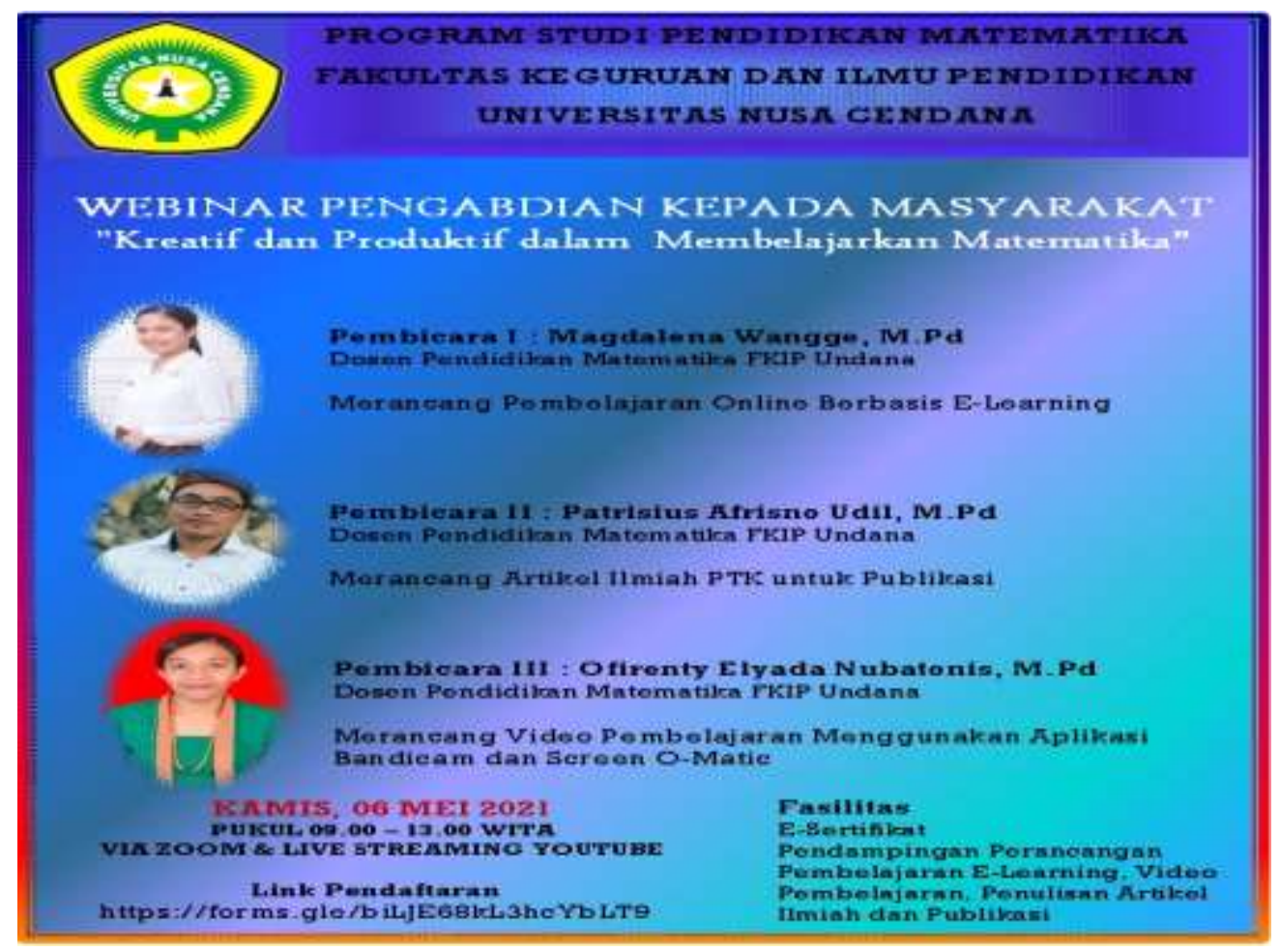

Gambar 1. Brosur undangan kegiatan pengabdian kepada masyarakat

\subsection{Bimbingan dan Pelatihan}

Kegiatan bimbingan dan pelatihan diberikan melalui kegiatan webinar ini, yang dilaksanakan dalam 2 hari, yaitu pada hari Kamis, 6 Mei 2021 dan hari Jumat, 7 Mei 2021. Pada hari pertama, webinar dilaksanakan untuk memberikan bimbingan terkait bagaimana prosedur serta konsep-konsep, dan faktor -faktor pendukung dalam merancang pembelajaran online berbasis e-learning ini. Tujuannya agar para guru dan calon guru terbantu dalam melaksanakan pembelajaran di tengah situasi pandemi, selain itu juga diharapkan agar tidak 
hanya sekedar merancang pembelajaran online berbasis e-learning dengan baik dan tepat tetapi juga paham apa itu e-learning, untuk apa e-learning ini perlu dirancang, serta meminimalisir permasalahan yang dapat menjadi kendala dalam proses penyusunan $e$ learning.

Kegiatan webinar ini dilaksanakan via Zoom meeting dan juga Live streaming YouTube, dengan diikuti oleh lebih dari 300 peserta baik para guru dan calon guru matematika atau dari bidang studi lain.
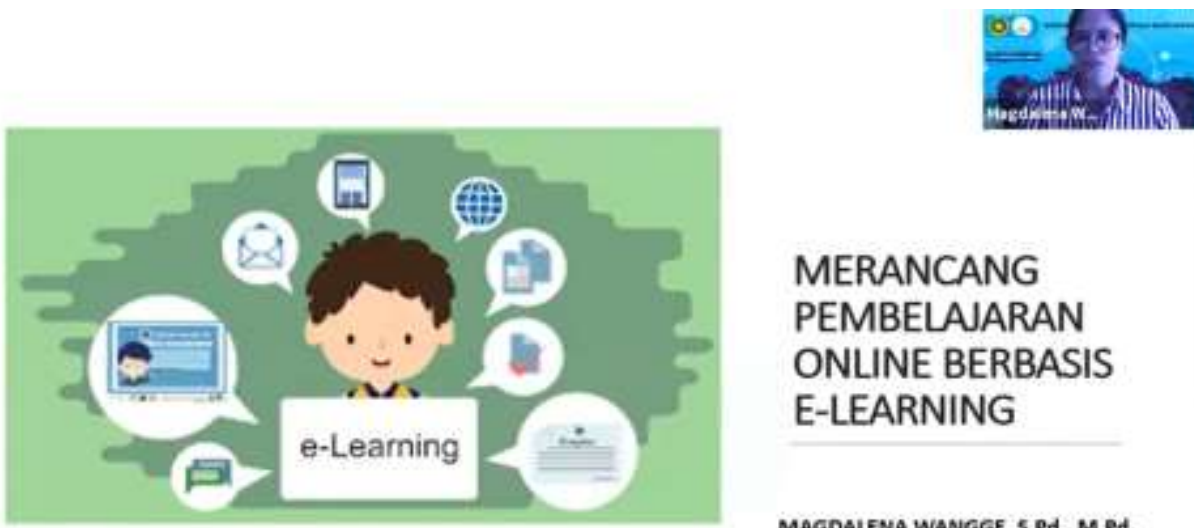

MERANCANG PEMBELAJARAN ONLINE BERBASIS E-LEARNING

MAGDALENA WANGGE, 5.Pd, M.Pd.

PERUBAHAN PARADIGMA DALAM PENDIDIKAN
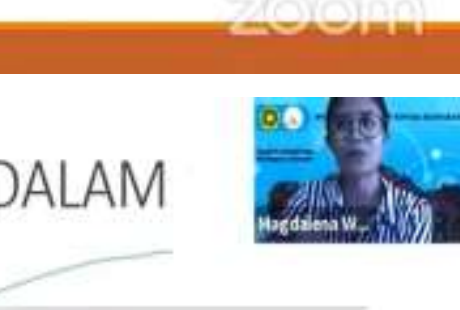

From teacher-centered instruction $\Rightarrow$ To student-centered instruction

From single-sense stimulation

To multisensory stimulation

From single-path progression

To multipath progression

From single media
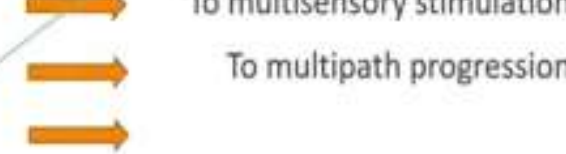

Gambar 2. Pembimbingan melalui webinar untuk merancang pembelajaran online berbasis $e$ learning

Pada hari kedua kegiatan webinar, diberikan pelatihan bagaimana merancang pembelajaran online berbasis e-learning. Banyak para peserta yang merancang e-learning dengan menggunakan media Whatsapp dan Web conference seperti zoom meeting, google meet, google classroom, Microsoft team, dan lain-lain. Peneliti tidak banyak menjelaskan 
bagaimana merancang pembelajaran online berbasis e-learning dengan berbagai platform tersebut, karena para peserta sudah sangat baik dalam menguasainya.

Para peserta justru meminta untuk diajarkan platform baru yang belum banyak mereka kenal, tapi sangat dikuasai dengan baik oleh peneliti sehingga dapat dibagikan kepada mereka. Oleh karena itu, peneliti menyarankan satu media platform yang cukup mudah digunakan dalam merancang pembelajaran online berbasis e-learning khususnya dalam mengatur sistematika pembelajaran online atau yang lebih dikenal dengan Learning Management System. Platform LMS tersebut adalah schoology.
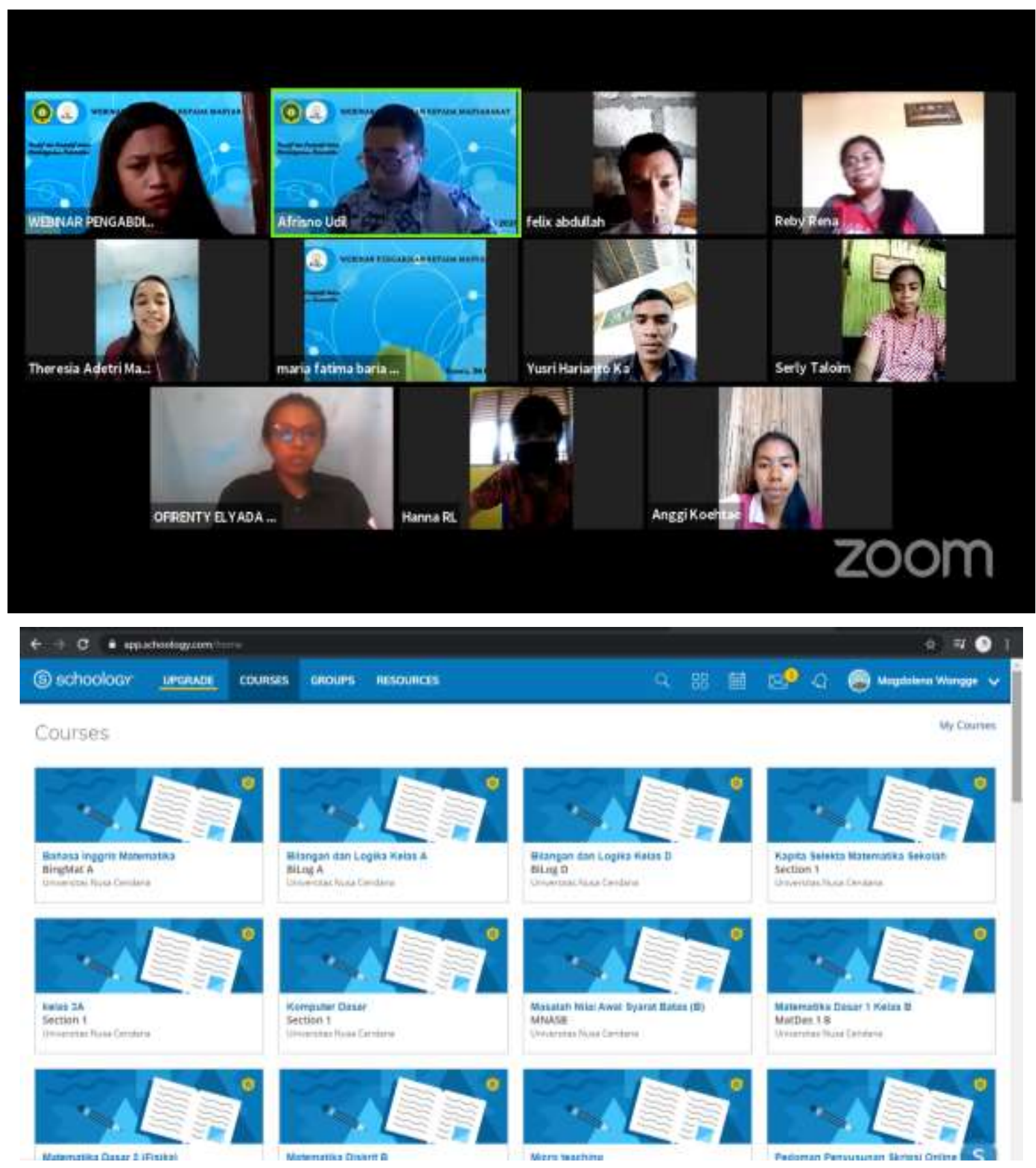

Gambar 3. Pelatihan melalui webinar untuk merancang pembelajaran online berbasis $e$ learning 
Pada kegiatan diskusi, dimana disediakan sesi tanya jawab. Ada beberapa yang cukup antusias untuk bertanya. Dan dari diskusi ini diperoleh beberapa hal sebagai berikut:

1) Peserta mulai dapat memahami dengan baik apa yang dimaksud dengan $e$-learning

2) Peserta merasa cukup terbantu dengan penjelasan peneliti tentang bagaimana merancang pembelajaran online berbasis e-learning

3) Ada beberapa peserta yang sudah menerapkan e-learning ini, menurut mereka rancangan pembelajaran seperti ini cukup efisien serta peserta didik pun bisa mengerjakannya di mana saja dan kapan saja

4) Ada peserta webinar yang tidak terlalu tertarik dengan pembelajaran online berbasis $e$ learning ini karena menurutnya malah mempersulit peserta didik dan membuat pekerjaan guru semakin banyak

5) Ada pula yang bertanya tentang media yang paling bagus digunakan. Peneliti menjelaskan bahwa tidak ada media yang paling bagus atau paling baik digunakan, namun ada media yang tepat dan sesuai untuk digunakan. Jadi perlu diperhatikan agar media yang digunakan sudah tepat dan sesuai dengan materi yang mau diajarkan dan kompetensi-kompetensi yang hendak dicapai pun sudah tepat.

6) Peserta ingin webinar seperti ini bisa sering diadakan, sehingga menambah wawasan mereka untuk melakukan inovasi dalam pembelajaran.

Tahap terakhir yaitu evaluasi, peneliti bersama kedua rekan dosen mengevaluasi semua proses kegiatan yang telah dilaksanakan dan diperoleh beberapa hal sebagai berikut:

1) Kegiatan pengabdian kepada masyarakat melalui webinar ini sudah berjalan dengan baik

2) Memfasilitasi jika ada peserta yang masih ingin belajar banyak terkait topik yang sudah diberikan, dalam hal ini materi dari peneliti yaitu merancang pembelajaran online berbasis e-learning

3) Mempublikasikan hasil kegiatan ini dalam bentuk artikel.

\section{Kesimpulan}

Dari kegiatan pengabdian ini dan berdasarkan tujuan yang ingin dicapai dari kegiatan ini, maka dalam merancang pembelajaran online berbasis e-learning, para guru dan calon guru perlu memperhatikan beberapa hal berikut:

1. Memahami tentang e-learning

2. Mengidentifikasi karakteristik dari setiap peserta didik

3. Mendesain dan mengembangkan materi yang interaktif

4. Menerapkan strategi mengajar yang tepat dalam menyampaikan materi secara elektronik

5. Mengorganisir materi secara baik agar mudah dipelajari peserta didik

6. Mengikuti berbagai pelatihan daring yang diadakan contohnya webinar untuk menambah pengetahuan dan kemampuan dalam merancang e-learning

7. Melibatkan diri dalam setiap tahapan mulai dari merencanakan, mengembangkan, hingga mengambil keputusan

8. Mengevaluasi pembelajaran, baik dari persepsi guru sendiri atau dari peserta didiknya.

\section{Acknowledgments}

Ucapan terima kasih, peneliti sampaikan kepada dua rekan dosen yang sudah bekerja sama merancang dan melaksanakan kegiatan webinar sebagai bentuk pengabdian kepada masyarakat dengan dana mandiri, serta pada kepala jurusan Pendidikan Matematika FKIP 
Universitas Nusa Cendana yang sudah memberi ijin kepada peneliti dan rekan dosen lain untuk melaksanakan kegiatan ini.

\section{References}

Dahiya, S. (2012). An E-learning System for Agricultural Education. Indian Research Journal of Extenation Education, 12(3), 132-135.

Firman, F., \& Rahman, S. R. (2020). Pembelajaran online di tengah pandemi covid-19. Indonesian Journal of educational Science, 2(2), 81-89.

Gikas, J., \& Grant, M. M. (2013). Mobile computing devices in higher education: student perspectives on learning with cellphones, smartphones \& social media. Internet and Higher Education, 19, 18-26.

Handarini, O. I., \& Wulandari, S. S. (2020). Pembelajaran daring sebagai upaya study from home (sfh) selama pandemi covid-19. Jurnal Pendidikan Administrasi Perkantoran, 8(3), 496-503.

Henderson, A. J. (2003). the e-learning question and answer book. Amacom.

Iftakhar, S. (2016). Google clasroom: What works and how?. Journal of Education and Social Sciences, 3. 12-18

Koran, J. K. C. (2002). Aplikasi E-learning dalam Pengajaran dan Pembelajaran di Sekolah Malaysia.

http://file.upi.edu/Direktori/FIP/JUR. PEND. LUAR_SEKOLAH/194704171973032-

MULIATI PURWASASMITA/APLIKASI E-

LEARNING DALAM PENGAJARAN DAN PEMBELAJARAN DI SEK.pdf

Korucu, A. T., \& Alkan, A. (2011). Differences between m-learning (mobile learning) and elearning, basic terminology and usage of m-learning in education. Procedia-Social and Behavioral Sciences. https://doi.org/10.1016/j. sbspro.2011.04.029.

Kristina, M., Sari, R. N., \& Nagara, E. S. (2020). Model pelaksanaan pembelajaran daring pada masa pandemi covid-19 di Provinsi Lampung. Jurnal Idaarah, 4(2), 200-209.

Kumar, V., \& Nanda, P. (2018). Social media in higher education: A framework for continuous engagement. International Journal of Information and Communication Technology Education. 15(1). 1-12. https://doi.org/10.4018/ijicte.2019010107.

Mahnun, N. (2018). Implementasi pembelajaran online dan optimalisasi pengelolaan pembelajaran berbasis online di perguruan tinggi Islam dalam mewujudkan world class university. IJIEM: Kajian Teori dan Hasil Penelitian Pendidikan, 1(1), 29-36.

Munir, M. (2009). Pembelajaran Jarak Jauh Berbasis Teknologi Informasi dan Komunikasi. Bandung: Alfabeta.

Oknisih, Yull, N. W., \& Suyoto. (2019). Penggunaan aplen (aplikasi online) sebagai upaya kemandirian belajar siswa. Prosiding Seminar Nasional Pendidikan Dasar, 1, 477-483. http://eproceedings.umpwr.ac.id/index.php/semnaspgsd/article/view/1056.

Seok, S. (2008). The Aspect of E-learning. International Journal on E-learning, Proquest, 7(4), 725-741

Sicat, A. S. (2015). Enhancing college students' proficiency in business writing via schoology. 
International Journal of Education and Research, 3 (1). 159-178

Smaldino, S. E., Lowther, D. L., \& Russell, J. D. (2007). Instruction technology and media for learning $9^{\text {th }}$ edition. Pearson.

So, S. (2016). Mobile instant messaging support for teaching and learning in higher education. Internet and Higher Education. https://doi.org/10.1016Zj.iheduc.2016.06.001.

Sutanta, E. (2009). Konsep dan Implementasi E-learning. IST Akprind

\section{Copyrights}

Copyright for this article is retained by the author(s), with first publication rights granted to the journal.

This is an open-access article distributed under the terms and conditions of the Creative Commons Attribution license (http://creativecommons.org/licenses/by/4.0/) 